\title{
Lipschütz ulcer (ulcus vulvae acutum) - a rare cause of genital lesion
}

Úlcera de Lipschütz (ulcus vulvae acutum) - uma causa rara de lesão genital

\author{
Ana Brinca ${ }^{1}$ \\ Maria João Carvalho ${ }^{3}$ \\ Américo Figueiredo ${ }^{4}$
}

\author{
Maria Miguel Canelas ${ }^{2}$ \\ Ricardo Vieira ${ }^{2}$
}

\begin{abstract}
Lipschütz Ulcer, or ulcus vulvae acutum, is a rare and probably underdiagnosed entity that usually presents as an acute painful vulvar ulcer in young women. The etiology is unknown, although recent reports have associated it with the Epstein-Barr virus. The diagnosis is made by exclusion after ruling out sexually transmitted diseases, autoimmune causes, trauma, and other etiologies of genital ulcerations. We report a case of a young woman who developed flu-like symptoms and painful vulvar ulcers. Complementary examinations ruled out sexually transmitted diseases and the other usual causes of genital ulcers; lesions healed with no sequelae or recurrences. This case represents a rare important differential diagnosis of genital ulceration.

Keywords: Genital diseases, female; Infectious mononucleosis; Ulcer

Resumo: A Úlcera de Lipschütz, ou ulcus vulvae acutum, é uma entidade rara mas provavelmente subdiagnosticada, que se apresenta como úlcera vulvar aguda dolorosa numa mulher jovem. A etiologia é desconhecida embora relatos recentes a tenham associado à primo-infecção pelo vírus Epstein-Barr. $\mathrm{O}$ diagnóstico é estabelecido após exclusão de doenças sexualmente transmissíveis, causas autoimunes, traumáticas e outras etiologias de úlceras genitais. Relatamos o caso de uma jovem que desenvolveu quadro gripal e dolorosas úlceras genitais. Os exames complementares excluiram doenças sexualmente transmissíveis e as outras causas habituais de ulceração genital. As lesões cicatrizaram sem sequelas e sem recorrências. Este caso representa um diagnóstico diferencial importante e raro de ulceração genital. Palavras-chave: Doenças dos genitais femininos; Mononucleose infecciosa; Úlcera
\end{abstract}

\section{INTRODUCTION}

Ulcus vulvae acutum is a rare disease characterized by a painful vulvar ulceration of non-venereal origin in young women. Numerous aetiologies have been proposed, including an association with EpsteinBarr virus infection. It seems to be a reactive process typically triggered by a distant infection. The ulcers are usually single, occasionally multiple, and resolve spontaneously in a few weeks.

\section{CASE REPORT}

A 30-year-old previously healthy woman, with no personal history of recurrent oral or genital apht-

\footnotetext{
Received on 25.07.2011.

Approved by the Advisory Board and accepted for publication on 18.09.2011.

* Study carried out at the Dermatology Service of University of Coimbra Hospitals (Hospitais da Universidade de Coimbra) - Coimbra, Portugal. Conflict of interest: None

Financial funding: None

Physician - Intern at the Dermatology Service of University of Coimbra Hospitals (Hospitais da Universidade de Coimbra) - Coimbra, Portugal.

Physician - Specialist in Dermatovenereology of the Dermatology Service of University of Coimbra Hospitals (Hospitais da Universidade de Coimbra) - Coimbra, Portugal.

Physician - Intern of Gynecology-Obstetrics at University of Coimbra Hospitals (Hospitais da Universidade de Coimbra) - Coimbra, Portugal.

Prof. Doctor - Director of the Dermatology Service of University of Coimbra Hospitals (Hospitais da Universidade de Coimbra) - Coimbra, Portugal. 
hous lesions, presented with sudden onset of two painful vulvar ulcers two days before, preceded by weakness, asthenia, sore throat and fever $\left(38-39^{\circ} \mathrm{C}\right)$. The patient reported a recent sexual contact with the usual partner. Physical examination revealed, on both labia minora, two ulcerated necrotic lesions, indurated, with well demarcated irregular margins, approximately $10 \mathrm{~mm}$ in diameter and surrounded by a purpuric halo (Figure 1). Bilateral painful inguinal lymph nodes were detected upon palpation. No vulvar swelling, vaginal discharge or lymphangitis were noticed. There were no other skin or mucous membrane lesions. Histopathologic examination was nonspecific, revealing a dense neutrophilic and lymphocytic infiltration with central necrotic areas (Figure 2). Analytically, there was an elevated C-reactive protein $(16 \mathrm{mg} / \mathrm{dL})$, no leukocytosis and no alterations in liver enzymes. Herpes simplex virus (HSV), cytomegalovirus (CMV), Treponema pallidum, Clamydia trachomatis and human immunodeficiency virus (HIV) serologies were all negative. There was evidence of prior Epstein-Barr virus infection (IgG positive, IgM negative). The patient was treated with oral metronidazole (250 mg bid) with clinical improvement and complete resolution of the lesions within a week. No recurrences occurred during a one-year period.

\section{DISCUSSION}

In 1913 Lipschütz first described an acute disease comprising fever, genital ulceration and lymphadenopathy in an adolescent girl. ${ }^{1}$ Etiology and pathogenesis are still unknown, but acute vulvar ulcers have been associated with infectious diseases such as Mycoplasma infection, paratyphoid fever, influenza A infection, and mostly with Epstein-Barr virus (EBV) infection. ${ }^{2 \cdot 9}$ The disease is characterized by an acute

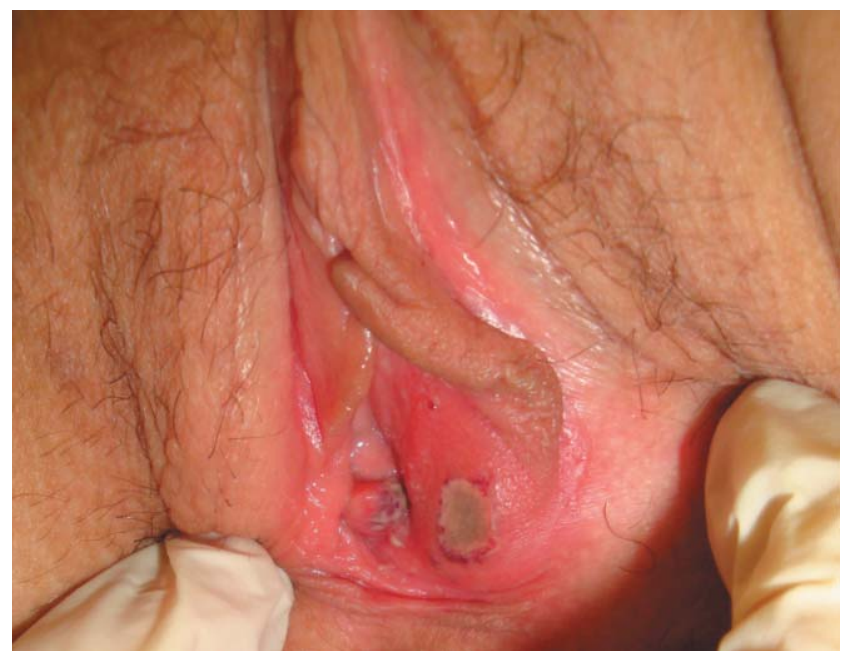

FIGURE 1: Vulvar ulcers on labia minora onset of flu-like symptoms such as malaise, fever, asthenia, myalgia, pharyngotonsilitis, lymphadenopathy and headache, with single or multiple deep and painful ulcers on the vulva, mainly on the inner aspect of labia minora. They usually occur in young women, predominantly virgins. ${ }^{1,10}$

The histologic examination is not of diagnostic value because findings are nonspecific: superficial edema and dilated capillaries with neutrophilic infiltration and ulceration. Initial workup may include complete blood cell count; bacterial culture; serologic test for syphilis, EBV, HIV; PCR assays for HSV; and skin biopsy from an ulcer edge if necessary.

Diagnosis of Lipschütz ulcer is mainly clinical, after exclusion of other causes of vulvar ulcers. The differential diagnosis is extensive and includes venereal and nonvenereal infections, noninfectious diseases, traumatic causes and malignant tumors (Chart 1).

The treatment is mainly symptomatic. Topical

CHART 1: Causes of vulvar ulcers

\begin{tabular}{|c|c|c|}
\hline Infectious & Nonvenereal & $\begin{array}{l}\text { Herpes simplex virus } \\
\text { Syphilis } \\
\text { HIV } \\
\text { Granuloma inguinale } \\
\text { Lymphogranuloma } \\
\text { venereum } \\
\text { Chancroid } \\
\text { Epstein-Barr virus } \\
\text { Candida } \\
\text { Bacteria } \\
\text { Parasites } \\
\text { Mycobacteria }\end{array}$ \\
\hline Noninfectious & \multicolumn{2}{|c|}{$\begin{array}{l}\text { Drug reaction (fixed drug eruption, } \\
\text { erythema multiforme, Stevens-Johnson } \\
\text { syndrome) } \\
\text { Pemphigus vulgaris } \\
\text { Bullous pemphigoid } \\
\text { Inflammatory bowel disease } \\
\text { Lichen planus } \\
\text { Lichen sclerosus } \\
\text { Idiopathic and secondary aphthae } \\
\text { Behçet's syndrome } \\
\text { Reiter syndrome } \\
\text { Pyoderma gangrenosum }\end{array}$} \\
\hline Traumatic & $\begin{array}{l}\text { Mechanical } \\
\text { Thermal } \\
\text { Chemical } \\
\text { Factitial }\end{array}$ & \\
\hline $\begin{array}{l}\text { Malignant } \\
\text { tumors }\end{array}$ & $\begin{array}{l}\text { Basal cell carc } \\
\text { Squamous ce } \\
\text { Extramammar } \\
\text { Leukemia/Lyn }\end{array}$ & $\begin{array}{l}\text { arcinoma } \\
\text { aget's disease } \\
\text { loma }\end{array}$ \\
\hline
\end{tabular}




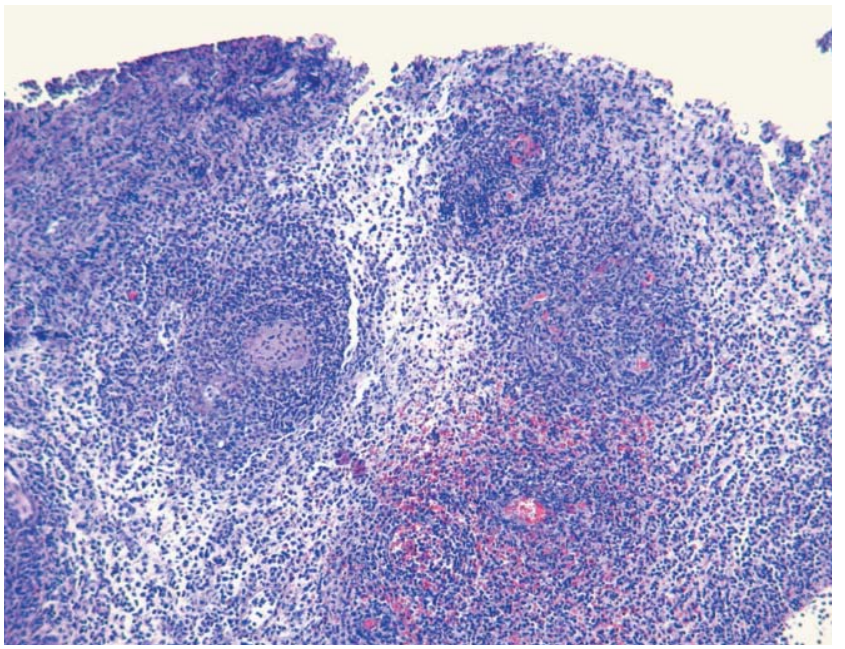

FIGURE 2: H\&E. dense neutrophilic and lymphocytic infiltration with central necrotic areas antibiotics can be used, as well as oral corticosteroids and oral antibiotics for peculiarly painful acute genital ulcers. The condition is self-limited and healing occurs spontaneously, with no recurrences, usually in 2 weeks.

It is important to remember this diagnosis, or patients with Lipschütz ulcers will continue to be treated for herpes simplex and other more frequent causes of genital ulceration, without any benefit.

\section{REFERENCES}

1. Lipschütz B. Uber eine eigenartige Geschwürsform des weiblichen Genitales (Ulcus vulvae acutum). Arch Dermatol Syph (Berlin). 1913;114:363-96.

2. Korting GW, Hinterberger G. Ulcus vulvae acutum with cold-agglutinin-positive, Mycoplasma-caused atypical pneumonia. Hautarzt. 1979;30:550-2.

3. Pelletier F, Aubin F, Puzenat E, Deprez P, Blanc D, Estavoyer JM, et al. Lipschütz genital ulceration: rare manifestation of paratyphoid fever. Eur $\mathrm{J}$ Dermatol. 2003;13:297-8.

4. Wetter DA, Bruce AJ, MacLaughlin KL, Rogers RS $3^{\text {rd }}$. Ulcus vulvae acutum in a 13-year-old girl after influenza A infection. Skinmed. 2008;7:95-8.

5. 5. Taylor S, Droke SM, Dedicoat M, Wood MJ. Genital ulcers associated with acute Epstein-Barr virus infection. Sex Transm Infect. 1998;74:296-7.

6. Halvorsen JA, Brevig T, Aas T, Skar AG, Slevolden EM, Moi H. Genital ulcers as initial manifestation of Epstein-Barr virus infection: two new cases and a review of the literature. Acta Derm Venereol. 2006;86:439-42.

7. Cheng SX, Chapman MS, Margesson LJ, Birenbaum D. Genital ulcers caused by Epstein-Barr virus. J Am Acad Dermatol. 2004;51:824-6.

8. Portnoy J, Ahronheim GA, Ghibu F, Clecner B, Joncas JH. Recovery of Epstein-Barr virus from genital ulcers. New Engl J Med. 1984;311:966-8.
9. Hudson LB, Periman SE. Necrotizing genital ulcerations in premenarcheal female with mononucleosis. Obstet Gynecol. 1998;92:185-7.

10. Farhi D, Wendling J, Molinari E, Raynal J, Carcelain G, Morand P, et al. Non-sexually related acute genital ulcers in 13 pubertal girls: a clinical and microbiological study. Arch Dermatol. 2009;145:38-45.

How to cite this article: Brinca A, Canelas MM, Carvalho MJ, Vieira R, Figueiredo A. Lipschütz ulcer (ulcus vulvae acutum) - a rare cause of genital lesion. An Bras Dermatol. 2012;87(4):622-4. 